\title{
Evidence for the Preferential Involvement of 5-HT2A Serotonin Receptors in Stress- and Drug-Induced Dopamine Release in the Rat Medial Prefrontal Cortex
}

\author{
Elizabeth A Pehek*, 1,2,3, Christine Nocjar ${ }^{1,3}$, Bryan L Roth ${ }^{1,2,4}$, Tara A Byrd ${ }^{3}$ and Omar S Mabrouk ${ }^{1,3}$ \\ 'Department of Psychiatry, Case Western Reserve School of Medicine, Cleveland, OH, USA; ${ }^{2}$ Department of Neurosciences, Case Western \\ Reserve School of Medicine, Cleveland, OH, USA; ${ }^{3}$ Louis Stokes Cleveland VA Medical Center, Cleveland, OH, USA; ${ }^{4}$ Department of Biochemistry, \\ Case Western Reserve School of Medicine, Cleveland, OH, USA
}

\begin{abstract}
The mechanism(s) by which serotonin modulates dopamine release in the medial prefrontal cortex is not known, although studies suggest an involvement of 5-HT2 family receptors. We employed in vivo microdialysis and putatively selective 5-HT2A antagonists (MI00907, MDL I 1,939, SR46349B) to determine if 5-HT2A receptors are responsible for both drug- and stress-induced DA release in the medial prefrontal cortex. MDL I I,939 and SR46349B receptor-binding studies indicated, for the first time, that only MDL I I,939 had greater selectivity for the 5-HT2A vs the 5-HT2C receptor subtypes similar to MI00907, and that both showed low or no affinity for non-5-HT2 receptors. Reverse dialysis with 5-HT2A antagonists had little or no effect on basal dopamine efflux. However, intracortical administration of MDL I 1,939 or MI00907 attenuated dopamine release induced by systemic administration of the 5-HT2 agonist DOI. Dual-probe microdialysis demonstrated that systemic DOI also increased glutamate concentrations in the ventral tegmental area (VTA). This was blocked by intracortical MI00907. Cortical perfusion with MI00907, or the atypical antipsychotic drug risperidone, but not the 5-HT2B/C ligand SB 206553, also decreased dopamine release induced physiologically by stress. These results indicate that stimulation of cortical 5-HT2A receptors increases the release of dopamine from the mesocortical system. They suggest that this effect may be mediated by increases in glutamate release from corticotegmental projections to the VTA. Additionally, they indicate that cortical 5-HT2A receptors modulate evoked dopamine release, such as that observed physiologically following mild stress. These findings may have implications for the pharmacological treatment of disorders resulting from or exacerbated by stress. Neuropsychopharmacology (2006) 3 I, 265-277. doi:I 0.1038/sj.npp. I3008 I9; published online 6 July 2005
\end{abstract}

Keywords: DOl; glutamate; MI00907; medial prefrontal cortex; schizophrenia; ventral tegmental area

\section{INTRODUCTION}

A common property of atypical antipsychotic drugs such as clozapine or risperidone is high affinity for the serotonin2A (5-HT2A) receptor subtype. However, it is clear that atypical antipsychotic drugs have appreciable affinities for most biogenic amine receptors (Roth et al, 2004). The apparent preferentially high affinity for 5-HT2A receptors led to the hypothesis that antipsychotic efficacy may be related to the ability of a drug to antagonize 5-HT2A receptors (Meltzer, 1989). Studies show that atypical antipsychotic drugs regulate dopamine (DA) release in the

\footnotetext{
*Correspondence: Dr EA Pehek, Departments of Psychiatry and Neurosciences, Case Western Reserve University School of Medicine, VA Medical Center I5I (W), I070 I East Blvd., Room K2 19, Cleveland, $\mathrm{OH}$ 44106, USA, Tel: + 2167913800 ext 4237, Fax: + 216229 8509, E-mail: eap6@cwru.edu

Received 9 February 2005; revised 29 April 2005; accepted 2 May 2005

Online publication: 3 June 2005 at http://www.acnp.org/citations/ Npp060305050087/default.pdf
}

medial prefrontal cortex (mPFC) (eg Moghaddam and Bunney, 1990; Pehek and Yamamoto, 1994). Since abnormalities in the mesocortical DA system have been associated with the negative symptoms of schizophrenia (Weinberger, 1987), it is possible that a causal link between 5-HT2A receptor antagonism, alterations in mesocortical DA release, and clinical efficacy exists.

Neurons in the mesocortical DA system originate in the ventral tegmental area (VTA) and project to the mPFC. Both the MPFC and VTA are innervated by serotonergic neurons originating in the dorsal raphe (Azmitia and Segal, 1978; Beart and McDonald, 1982). Immunohistochemical studies indicate the presence of 5-HT2A receptors in both the PFC (Willins et al, 1997; Jakab and Goldman-Rakic, 1998; Miner et al, 2003) and VTA (Doherty and Pickel, 2000; Nocjar et al, 2002) where they could, at least in theory, modulate DA neuronal activity. In the mPFC, the vast majority of 5-HT2A receptors are localized to the apical dendrites of pyramidal cells and, to a lesser extent, GABAergic interneurons (Willins et al, 1997; Jakab and GoldmanRakic, 1998; Miner et al, 2003). Thus, regulation of 
mesocortical DA by cortical 5-HT2A receptors could be a local effect or possibly involve a polysynaptic neural circuit.

Previous studies have suggested that 5-HT2 family receptors may regulate mesocortical DA neuronal activity. Systemic administration of DOI, a nonsubtype-selective 5HT2A/B/C agonist, increased cortical DA efflux which could be blocked by the 5-HT2A-preferring antagonist M100907 $\left(K_{\mathrm{i}}=1.92\right.$ for $\mathrm{r} 5-\mathrm{HT} 2 \mathrm{~A}$ : see on-line database: http://kidb. case.edu/pdsp.php; Gobert and Millan, 1999). This effect is also observed when M100907 is infused directly into the cortex, suggesting a role for mPFC 5-HT2A receptors (Pehek et al, 2001). Unfortunately, M100907 has appreciable affinities for 5-HT2C $\left(K_{\mathrm{i}}=88 \mathrm{nM}\right.$; http://kidb.case.edu/ pdsp.php) and many other biogenic amine receptors including $\alpha 1$ - and $\alpha 2$-adrenergic and D1-dopamine receptors (http://kidb.case.edu/pdsp.php). The primary goal of the present study was to determine the local 5-HT2 receptor subtype responsible for regulating phasic DA release in the mPFC. To accomplish this, we examined a panel of potent 5-HT2A receptor antagonists (M100907, MDL 11,939, and SR46349B) along with a highly selective 5-HT2B/C inverse agonist SB 206553. Since the actual selectivity of these putatively 'selective' compounds is not known, receptorbinding studies were conducted to determine the preferential 5-HT2A vs 5-HT2C receptor affinities of MDL 11,939 and SR46349B, compared to M100907. The effect of intracortical administration of these antagonists on basal DA efflux was first determined to see whether the reported negligible role of cortical 5-HT2A receptors for basal DA function (Pehek et al, 2001) would be further confirmed. 5 -HT2 receptor subtype involvement in DA release evoked by administration of the 5-HT2 agonist DOI was then determined using the 5-HT2 receptor antagonists that showed preferential binding for the 5-HT2A vs 2C receptor in the receptor-binding study above. Glutamate was also measured in the VTA after DOI and M100907 administration to begin to assess whether corticotegmental mechanisms might potentially mediate the effects of DOI on cortical DA release. And finally, we assessed whether mPFC 5-HT2 family receptors may modulate mesocortical DA release induced by natural physiological phenomena. Since mesocortical dopamine neurons are extremely responsive to stress (Thierry et al, 1976; Abercrombie et al, 1989; Sorg and Kalivas, 1993; Feenstra and Botterblom, 1996; Inglis and Moghaddam, 1999), and stress increases 5-HT in the mPFC (eg Kawahara et al, 1993), we examined the effect of cortical administration of the 5-HT2A receptor antagonist M10097 on DA release induced physiologically by stress $(20 \mathrm{~min}$ of gentle handling). To assess the potential involvement of other 5-HT2 receptor subtypes, these results were contrasted with those following cortical administration of the selective 5-HT2B/C inverse agonist, SB 206,553. To extend the results to agents employed clinically, the atypical antipsychotic drug risperidone, which is a potent 5-HT2A antagonist $\left(K_{\mathrm{i}}=0.26\right.$ at $\mathrm{r} 5$-HT2A $)$ and weak 5-HT2C antagonist $\left(K_{\mathrm{i}}=87 \mathrm{nM}\right)$, was also tested (http://kidb.case. edu/pdsp.php). It was hypothesized that intracortical infusions of 5-HT2A antagonists would attenuate DOI and stress-induced DA release. It was further posited that DOI administration would increase VTA dialysate glutamate levels through an interaction with cortical 5-HT2A receptors. Our results demonstrate that 5-HT2A receptors modulate both drug- and stress-induced DA release in the $\mathrm{mPFC}$ and that some of the effects of atypical antipsychotic drugs such as risperidone on DA release are most likely mediated via 5-HT2A receptor blockade.

\section{MATERIALS AND METHODS}

\section{Receptor-Binding Studies}

Receptors. Cell lines stably transfected with recombinant cDNA encoding receptors or cell lines that express endogenous receptors were used for the comprehensive screening using the resources of the National Institute of Mental Health's Psychoactive Drug Screening Program (PDSP) as previously detailed (Roth et al, 2002). The recombinant receptors included (1) human adrenergic receptors, $\alpha 1 \mathrm{~A}, \alpha 1 \mathrm{~B}, \alpha 2 \mathrm{~A}, \alpha 2 \mathrm{~B}, \alpha 2 \mathrm{C}$, and rat adrenergic receptors, $\beta 1$ and $\beta 2$; (2) rat cannabanoid $\mathrm{CB} 1$ receptor; (3) dopaminergic receptors, hD1, rD2, rD3, rD4, and hD5; (4) human histamine receptors, $\mathrm{H} 1, \mathrm{H} 2$, and $\mathrm{H} 4$; (5) rat imidazoline receptor; (6) human muscarinic acetylcholine receptors, M1, M2, M3, M4, and M5; (7) human nicotinic acetylcholine receptors, $\alpha 2 / \beta 2, \alpha 2 / \beta 4, \alpha 3 / \beta 2, \alpha 3 / \beta 4, \alpha 4 / \beta 2$, and $\alpha 4 / \beta 4$; (8) human opiate receptors, $\mu, \delta$, and $\kappa$; (9) human peptide receptors, V1, V2, V3, and OT; (10) serotonergic receptors, h5-HT1A, r5-HT1B, h5-HT1E, r5HT2A, h5-HT2B, r5-HT2C, h5-HT3, h5-HT5A, h5-HT6, and h5-HT7; (11) human transporters of serotonin, norepinephrine, and dopamine as previously described (Roth et al, 1998; Rothman et al, 2000; Roth et al, 2001; Roth et al, 2002; Shapiro et al, 2002); and (12) rat metabotropic glutamate receptors, mGluR1a, mGluR2, mGluR4, mGluR5a, mGluR6, and mGluR8 as previously described (Gomeza et al, 1996; Wroblewska et al, 1997; Kozikowski et al, 1998; Shi et al, 2003). The endogenous receptors included (1) GABA receptors, $G_{A B A}, G A B A_{B}$, and $G_{A B A}$ BZP from rat forebrain; (2) histamine receptor $\mathrm{H} 1$ from rat forebrain; (3) rat nicotinic acetylcholine receptor, $\alpha 4 / \beta 2$; (4) ionotropic NMDA glutamate receptor from rat forebrain; and (5) voltage-sensitive $\mathrm{Ca}^{2+}$ channel from rat heart. For the cloned receptors, HEK-293 cells were either stably or transiently transfected with the receptor of interest with the following exceptions: muscarinic receptors were expressed in CHO cells (see Davies et al (2005) for details) and r5HT2A and r5HT2C receptors were expressed in stable cell NIH 3T3 cell lines.

Radioligand competitive binding assays. Receptor-binding affinities were determined by radioligand competitive binding experiments. The assays were performed as previously detailed using cloned receptor preparations (Roth et al, 1998, 2001; Rothman et al, 2000; Shapiro et al, 2002), or with forebrain membrane preparations containing the endogenous receptors of interest (Roth et al, 1991).

Competitive binding assays were carried out under standard conditions as detailed previously (Roth et al, 2001, 2002; Rothman et al, 2000). The conditions for the different binding assays and $K_{\mathrm{i}}$ values for reference ligands are as described previously (Shi et al, 2003). On-line protocols for binding assays are available at http:// 
pdsp.cwru.edu/nimh/binding.htm. Binding data were performed in quadruplicate.

\section{Microdialysis Studies}

Animals. Male Sprague-Dawley rats (Zivic Miller, Alison Park, PA or Harlan, Indianapolis, IN), weighing between 200 and $350 \mathrm{gm}$ at the time of surgery, were used for all experiments. Rats were housed two per cage in a temperature-controlled room with a $12 / 12 \mathrm{~h}$ light/dark cycle. Food and water were available ad libitum. All animal procedures were in strict accordance with the NIH Guide for the Care and Use of Laboratory Animals and were approved by the local animal care committee. All efforts were made to minimize the number of animals used and their suffering.

Surgery. Rats were anesthetized with a mixture of xylazine and ketamine (6 and $70 \mathrm{mg} / \mathrm{kg}$, respectively; administered i.m.) and mounted on a stereotaxic frame. After dura was removed, $21 \mathrm{~g}$ stainless steel guide cannulae were mounted on the brain surface above the mPFC $(+3.2 \mathrm{AP}$, ML 0.8) (Paxinos and Watson, 1998). For dual-probe studies, a second cannula was mounted above the VTA ( $-5.60 \mathrm{AP}, \mathrm{ML}$ 0.6). The cannulae, with wire obturators, were secured in place with three set screws covered with cranioplastic cement. Animals were returned to the colony room, singly housed and allowed to recover for 2-5 days prior to the experiments. Probe locations were verified histologically at the completion of the experiments. If improperly placed, the animal was excluded from the experiment.

Microdialysis. Microdialysis probes were of a concentric flow design (Yamamoto and Pehek, 1990). mPFC probes were constructed with a $5.0 \mathrm{~mm}$ active dialyzing surface membrane (Spectra/Por Hollow, MW cutoff $=13000$, diameter $=240 \mu \mathrm{m})$ to effectively dialyze from the dorsal anterior cingulate to the most ventral region of the infralimbic mPFC. VTA probes were constructed with a $1.0 \mathrm{~mm}$ active dialyzing surface at the most ventral extention of the probe to effectively dialyze the mediolateral parabrachial and paranigral VTA. The afternoon prior to microdialysis experiments animals were placed in clear plexiglas microdialysis chambers (Harvard Apparatus) with food and water available ad libitum. Probes were lowered slowly through the guide cannulae of awake rats and secured in place with cyanoacrylate glue. Animals were then returned to their dialysis chambers and tethered to counterbalance arms (Instech, Plymouth Meeting, PA) that permitted free movement about the chamber. A microinfusion pump (PHD 2000 ${ }^{\mathrm{TM}}$, Harvard Apparatus) and liquid swivel (Instech) were used to perfuse a modified Dulbecco's artificial cerebrospinal fluid (aCSF) buffer solution ( $137 \mathrm{mM}$ $\mathrm{NaCl}, 3 \mathrm{mM} \mathrm{KCl}, 1.2 \mathrm{mM} \mathrm{MgSO}$, $0.4 \mathrm{mM} \mathrm{KH}_{2} \mathrm{PO}_{4}$, with $1.2 \mathrm{mM} \mathrm{CaCl}{ }_{2}$ and $10 \mathrm{mM}$ glucose; $\mathrm{pH}$ 7.4) through the probes. After baseline collections, drugs dissolved in the aCSF were administered by reverse dialysis. Tubing connections were switched manually while maintaining a constant flow rate and collection volume. Samples were immediately analyzed for DA content and frozen for later assay of glutamate.
Drugs. $( \pm)$-DOI hydrochloride, $( \pm)$-2,5-Dimethoxy-4-iodoamphetamine hydrochloride, was obtained from SigmaAldrich (St Louis, MO). M100907, $R-(+)-4$-[1-hydroxy1-(2,3-dimethoxyphenyl)methyl]- $\mathrm{N}$-2-(4-flouro-phenylethyl)piperidine, was kindly donated by Marion Merrell Dow; risperidone was kindly donated by Janssen Pharmaceutica; SB 206553, N-3-Pyridinyl-3,5-dihydro-5-methylbenzo(1,2-b:4, 5-b')dipyrrole-1 $(2 H)$ carboxamide hydrochloride 5-methyl-1(3-pyridylcarbamoyl)-1,2,3,5-tetrahydropyrrolo[2,3-f]indole, was kindly donated by Smithkline and Beecham; and SR 46349B, trans, 4-([3Z)3-(2-dimethylaminoethyl)oxyimino3(2-flurophenyl +++ )propen-1-yl]phenol hemifumarate, was kindly donated by Sanofi Recherche. MDL 11,939, $\alpha$ Phenyl-1-(2-phenylethyl)-4-piperidinemethanol, was purchased from Tocris Cookson (Bristol, UK). For intracortical administration, all drugs were initially dissolved in water containing $1.5-5 \mu \mathrm{l}$ of glacial acetic acid to make a $10 \mathrm{mM}$ stock solution. They were then further diluted to $1.0-10.0 \mu \mathrm{M}$ concentrations with aCSF. Concentations refer to the base forms of the antagonists. The $\mathrm{pH}$ of all aCSF solutions was adjusted to 7.4. DOI was injected systemically (s.c.) and was dissolved in water $(2.5 \mathrm{mg} / \mathrm{kg} / \mathrm{ml}$, dose refers to the salt).

Chromatography. HPLC with electrochemical detection was used to measure dialysate DA, 5-HT, and glutamate content.

$D A$ and 5-HT: DA and 5-HT concentrations in dialysate samples were measured by reverse phase HPLC coupled with electrochemical detection. In total, $20 \mu \mathrm{l}$ samples were injected immediately after collection onto a $2 \times 100 \mathrm{~mm}$ Phenomenex (Torrance, CA) column (Ultracarb ${ }^{\mathrm{TM}}, 3 \mu \mathrm{m}$ particle size, ODS 20). The mobile phase consisted of $32 \mathrm{mM}$ anhydrous citric acid, $54 \mathrm{mM}$ sodium acetate trihydrate, $0.074 \mathrm{mM}$ EDTA, $0.215 \mathrm{mM}$ octylsulfonic acid, and $3 \%$ methanol (vol/vol), $\mathrm{pH}$ 4.2. To maintain separation of DA and 5-HT from its metabolites and 5-hydroxyindoleacetic acid, the $\mathrm{pH}$ of the mobile phase and the concentration of the octylsulfonic acid were adjusted as needed. A BAS LC4C or Antec INTRO electrochemical detector with a glassy carbon electrode, maintained at a potential of $+0.60 \mathrm{~V}$ relative to an $\mathrm{Ag} / \mathrm{AgCl}$ reference electrode, was employed.

Glutamate: Frozen dialysate samples were defrosted and $14 \mu \mathrm{l}$ was placed into a refrigerated autosampler (ThermoQuest, Thermo Separation Products, San Jose, CA). Samples were precolumn derivatized with ophthaldehyde (OPA) using a slightly modified version of the procedure of Donzanti and Yamamoto (1988). The derivatizing solution was prepared by mixing $27 \mathrm{mg}$ OPA with $1 \mathrm{ml}$ methanol. Then, $9 \mathrm{ml}$ of $0.05 \mathrm{M}$ sodium tetraborate and $5.0 \mu \mathrm{l}$ of $\beta$ mercaptoethanol were added. This mixture was diluted further with sodium tetraborate $(1: 3)$. Next, $7 \mu$ of this solution was automatically mixed with the sample and then $10 \mu \mathrm{l}$ was injected onto a $2 \times 100 \mathrm{~mm}$ Phenomenex column (Ultracarb $^{\mathrm{TM}}, 3 \mu \mathrm{m}$ particle size, ODS 20 ), maintained at $35^{\circ} \mathrm{C}$. The mobile phase consisted of $14.2 \mathrm{~g} \mathrm{Na}_{2} \mathrm{HPO}_{4}, 0.5 \mathrm{~g}$ $\mathrm{Na}_{2}$ EDTA, 25\% methanol, and $\mathrm{pH}$ 4.2. A Bioanalytical Systems LC-4C electrochemical detector with a glassy carbon electrode was used to detect the derivatized amino acids and was maintained at a potential of $0.6 \mathrm{~V}$ (range $20 \mathrm{nA} / \mathrm{V})$. 
Histology. After microdialysis experiments were completed, probe placements were verified histologically. Only animals, whose probe placements were verified to be in the MPFC, or the mPFC and the VTA for the dual probe study, were used in this study.

Data analysis. Microdialysis data were expressed as the percentage of the average baseline level (last three baseline samples prior to treatment). Two-way ANOVAs, with drug group as the between factor and time as the within factor, were used to analyze data between drug treatment groups. One-way repeated measures ANOVAs, with time as the within factor, were used to analyze data from individual drug treatment groups. Following significant F-values, Dunnett's post hoc tests for comparing treatment means with a control were employed.

\section{Procedures}

Receptor-binding properties of two 5-HT2A antagonists: $M D L 11,939$ and $S R$ 46349B. This experiment screened the receptor-binding properties of MDL 11,939 and SR 46349B. If a compound displaced radioligand binding by $50 \%$ or more, then its $K_{\mathrm{i}}$ was determined as detailed above.

Effects of the 5-HT2A antagonists MDL 11,939 and SR $46349 B$ on cortical DA release. This experiment investigated the effects of intracortical administration of MDL 11,939 and SR 46349B on basal DA efflux in the mPFC. In addition, since Experiment 1 determined that MDL 11 939, but not SR46349B, showed strong preferential selectivity for the 5-HT2A $v s$ the 5-HT2C receptor, we examined the effects of this ligand on 5-HT2 agonist (DOI)-stimulated DA release. At 2-4 days after rats had been implanted with cannulae above the mPFC, microdialysis probes were lowered slowly through the cannulae. After 18-24h, aCSF perfusion began at a rate of $1.0 \mu \mathrm{l} / \mathrm{min}$. Samples were collected every $30 \mathrm{~min}$ for immediate determination of DA in the mPFC. After baselines had stabilized (approximately $3 \mathrm{~h}$ ), either SR 46349B or MDL 11,939 was perfused through the mPFC of two separate groups of rats to test the effect of 5HT2A receptor antagonism on basal DA efflux. SR 46349B was perfused through the mPFC for $1 \mathrm{~h}$ at a concentration of $1.0 \mu \mathrm{M}$ followed by $1 \mathrm{~h}$ at a concentration of $10 \mu \mathrm{M}$ as similarly tested with M100907 (Pehek et al, 2001). MDL 11,939 was perfused at a $10 \mu \mathrm{M}$ concentration for $3 \mathrm{~h}$. To test the effect of 5HT2A receptor antagonism on drug-induced DA efflux, one group of rats was injected with DOI $(2.5 \mathrm{mg} /$ $\mathrm{kg}$ s.c.) $30 \mathrm{~min}$ after perfusion with $1.0 \mu \mathrm{M}$ MDL 11,939 began (Pehek et al, 2001). This group was compared to a group receiving DOI injection and drug-free aCSF and a control group that received vehicle injections but no drug.

5-HT2A receptor regulation of stress-induced DA release in the PFC. This study determined whether intracortical infusions of the 5-HT2A antagonist M100907 would attenuate DA efflux elicited by a mild stress. Since M100907 has been extensively utilized in the literature to assess 5-HT2A receptor function compared to MDL 11,939, and we previously found that cortical $10 \mu \mathrm{M}$ M100907 blocked DOI-induced DA release in the mPFC (Pehek et al,
2001), it was implemented in this study to begin to assess 5HT2A receptor mechanisms in stress-induced cortical DA release. This concentration of M100907 does not alter basal DA levels in the mPFC (Pehek et al, 2001). Probes were lowered into guide cannulae placed over the MPFC in awake rats $18-24 \mathrm{~h}$ before the experiment began. At the start of the experiment, probes were perfused at a rate of $1.5 \mathrm{ml} / \mathrm{min}$ and samples were collected every $20 \mathrm{~min}$ until baselines were stable. A $10 \mu \mathrm{M}$ concentration of M100907 or drug-free aCSF was then perfused through the probes in two separate groups of rats. After $20 \mathrm{~min}$, rats were stressed for $20 \mathrm{~min}$. The stressor consisted of gentle stroking ('petting'), a procedure which reliably increases DA effux in rats (Inglis and Moghaddam, 1999). In M100907-treated animals, drug infusion continued during the stressor and until the end of the experiment. These results were compared to those following $10 \mu \mathrm{M}$ infusions of the selective $5-\mathrm{HT} 2 \mathrm{~B} / \mathrm{C}$ inverse agonist SB 206553. Local administration of $10 \mu \mathrm{M}$ SB206553 does not alter basal DA levels in the MPFC (Alex et al, 2005).

Effects of risperidione on stress-induced DA release in the $M P F C$. This experiment examined whether administration of risperidone by reverse dialysis would alter handlinginduced cortical DA efflux. Procedures were the same as the previous experiment except risperidone was infused beginning $40 \mathrm{~min}$ before the stressor was applied, to show that basal DA efflux was stable prior to stress application. Risperidone increases DA release in the mPFC when administered systemically, but cortical application of selective 5-HT2A antagonists do not (see Discussion). These results were compared to a control group that received aCSF without drug.

Cortical 5-HT2A receptor regulation of mesocortical DA and corticotegmental glutamate. This experiment investigated the regulation of DA efflux in the mPFC and glutamate in the VTA by 5-HT2A receptors in the mPFC. Due to the extensive use of M100907 in the literature, and to tie the findings in this study to previous results (Pehek et al, 2001), we used $10 \mu \mathrm{M}$ M100907 to assess cortical 5-HT2A receptor involvement. Rats were implanted with two cannulae: one above the mPFC and one above the VTA. After 2-4 days, on the morning of the experiment, microdialysis probes were lowered slowly through these cannulae. aCSF was then perfused immediately at a rate of $1.0 \mu \mathrm{l} / \mathrm{min}$ through both probes. This procedure of initiating the experiment immediately following probe insertion was utilized because we and others have found that brain injuryderived, that is, non-neuronal, levels of glutamate are higher 18-24 h following probe implantation (Obrenovitch et al, 1993; Xue et al, 1996). Samples were collected every $30 \mathrm{~min}$ for immediate determination of DA in the mPFC and subsequent determination of glutamate in the VTA. The VTA dialysate was frozen for later analysis of glutamate. Samples were collected until baseline dopamine levels were stable (approximately $3 \mathrm{~h}$ after probe implantation). A $10 \mu \mathrm{M}$ solution of M100907 or aCSF without drug (control) was then infused into the mPFC. After $30 \mathrm{~min}$, half of each group also received either an injection of the 5-HT2 agonist DOI $(2.5 \mathrm{mg} / \mathrm{kg}$ s.c.) or vehicle (water). This created four treatment groups: (1) intracortical M100907 and s.c. DOI, 
(2) intracortical aCSF and s.c. DOI, (3) intracortical M100907 and s.c. vehicle, and (4) intracortical aCSF and s.c. vehicle. Only animals with correct placements in both the VTA and mPFC were included in data analysis.

\section{RESULTS}

\section{Receptor-Binding Properties of Two 5-HT2 Antagonists: MDL 11,939 and SR 46349B}

Both MDL 11,939 and SR 46349B had high affinities for 5 -HT2A receptors $\left(K_{\mathrm{i}}(\mathrm{nM})=2.89\right.$ and 0.95 , respectively, see Table 1). However, these ligands differed with respect to their affinities for 5-HT2C receptors. While SR 46349B had high affinity for 5-HT2C receptors $\left(K_{\mathrm{i}}=8.24\right)$, MDL 11,939 had relatively low affinity $\left(K_{\mathrm{i}}=853.6\right)$. Thus, of the two ligands, MDL 11,939 was the most selective. For comparison, the putatively selective 5-HT2A antagonist M100907 has higher affinity for the 5-HT2A $\left(K_{\mathrm{i}}=1.92\right) v s$ the 5-HT2C $\left(K_{\mathrm{i}}=88\right)$ receptor (data from PDSP data base: http:// kidb.case.edu/pdsp.php). Both MDL 11,939 and SR 46349B had low or no affinity for non-5-HT2 receptors (see Table 1). M100907 has been previously reported to have appreciable affinity for various adrenergic receptors, H1-histamine, and sigma receptors and low affinities for D1 and D4 dopamine receptors (http://kidb.case.edu/pdsp.php).

\section{Effects of the 5-HT2A Antagonists MDL 11,939 and} SR 46349B on Cortical DA Release

Figure 1a illustrates the location of dialysis probes within the mPFC for this and subsequent experiments. Figure 2a shows that intracortical perfusion with either 1.0 or $10 \mu \mathrm{M}$ SR 46349B $(n=7)$ or $10 \mu \mathrm{M}$ MDL $11,939(n=5)$ did not significantly alter basal DA efflux (average basal levels of DA for these two groups were $0.56 \pm 0.07 \mathrm{pg} / 20 \mu \mathrm{l})$. As shown in Figure 2b, intracortical MDL 11,939 pretreatment blocked DOI-induced DA release in the mPFC. A two-way ANOVA (drug group $\times$ time) indicated that extracellular DA levels were significantly different in animals treated systemically with vehicle, DOI alone, or DOI plus intracortical MDL 11,939 (overall drug group effect: $\mathrm{F}(2,19)=4.47$, $p=0.03$ ). Indeed, rats treated with DOI alone showed significantly higher DA levels than MDL 11,939+DOIcotreated rats (drug group effect: $\mathrm{F}(1,13)=4.67, p=0.05$ ). Post hoc one-way ANOVAs (time) revealed that animals treated with DOI alone showed significantly increased dialysate DA levels following treatment (time effect: $\mathrm{F}(6,54)=$ $4.18, p=0.002 ; n=10$; see DOI group Figure $2 \mathrm{~b}$ ), while vehicle controls $(n=7)$ and animals cotreated with DOI plus intracortical MDL $11,939(1 \mu \mathrm{M}, n=5)$ did not ( $p$ 's $>0.05)$. Average basal DA levels for these last three groups were $0.41 \pm 0.04 \mathrm{pg} / 20 \mu \mathrm{l}, n=22$ ).

\section{5-HT2A Receptor Regulation of Stress-Induced DA Release in the mPFC}

As shown in Figure 3, mild handling (stroking) for $20 \mathrm{~min}$ increased DA to $182 \%$ of baseline (time effect: $\mathrm{F}(5,50)=$ $4.73, p=0.001, n=11$, average basal levels $=0.38 \pm 0.06 \mathrm{pg} /$ $20 \mu \mathrm{l}$ ). 5-HT was also increased to $197 \%$ (time effect: $\mathrm{F}(5,55)=8.30, \quad p<0.001, n=12$, see Figure 3, basal
Table I $K_{i}$ Values of MDL II,939, SR 46349B (mean \pm SEM) and MI00907 ${ }^{a}$ in Competitive Binding Assays

\begin{tabular}{lllc}
\hline & \multicolumn{3}{c}{ Drugs } \\
\cline { 2 - 4 } $\begin{array}{l}\text { Membrane-bound } \\
\text { proteins }\end{array}$ & MDL I I,939 & SR 46349B & M $\mathbf{0 0 9 0 7}$ \\
\hline $\begin{array}{llll}\text { Receptors } \\
\text { Serotonin }\end{array}$ & & \\
5-HTIA & $3416 \pm 1069$ & $2500 \pm 410$ & $>10000$ \\
r5-HTIB & $70.46 \pm 23.0$ & $914 \pm 314$ & $>10000$ \\
5-HTIE & No binding & No binding & $>10000$ \\
r5-HT2A & $2.893 \pm 0.56$ & $0.9507 \pm 0.11$ & 1.92 \\
5-HT2B & $1419 \pm 150$ & NT & 261 \\
r5-HT2C & $853.6 \pm 185.6$ & $8.243 \pm 1.37$ & 88 \\
5-HT3 & No binding & No binding & $>10000$ \\
5-HT5a & No binding & $1750 \pm 435$ & $>10000$ \\
$5-H T 6$ & $2752 \pm 1014$ & $3868 \pm 933$ & 5000
\end{tabular}

\section{Dopamine}

$\begin{array}{lllr}\text { DI } & 327.2 \pm 43.8 & >10000 & 2964 \\ \text { rD2 } & \text { No binding } & \text { No binding } & >10000 \\ \text { rD3 } & \text { No binding } & >10000 & >10000 \\ \text { D4 } & 3934 \pm 1334 & \text { NT } & >10000 \\ \text { D5 } & 2869+646 & \text { NT } & >10000\end{array}$

Acetylcholine (muscarinic)

$\begin{array}{llll}\text { MI } & \text { No binding } & 732.7 \pm 44.30 & >10000 \\ \text { M2 } & \text { No binding } & |3800 \pm 108| & >10000 \\ \text { M3 } & \text { No binding } & 2387 \pm 255.2 & >10000 \\ \text { M4 } & \text { No binding } & 3672 \pm 513.2 & >10000 \\ \text { M5 } & \text { No binding } & 3015 \pm 203.0 & >10000\end{array}$

$\begin{array}{cccc}\text { Adrenergic } & & & \\ \text { Alpha2A } & 1586 \pm 263.7 & 725.9 \pm 86.06 & 1900 \\ \text { Alpha2C } & 1186 \pm 118.6 & 2118 \pm 84.37 & 1442 \\ \text { AlphalA } & 1876 \pm 51.72 & \text { No binding } & 128 \\ \text { AlphalB } & 1579 \pm 117.9 & \text { No binding } & 424.7 \\ \text { rBeta2 } & \text { No binding } & \text { No binding } & >10000\end{array}$

$\begin{array}{llll}\text { Serotonin } & 2598 \pm 417 & \text { No binding } & >10000 \\ \text { Norepinephrine } & >10000 & 739.5 \pm 136.4 & >10000 \\ \text { Dopamine } & >10000 & 5619 \pm 1817.3 & >10000\end{array}$

\begin{tabular}{|c|c|c|}
\hline $\mathrm{hHI}$ & $1604 \pm 282.6$ & No binding \\
\hline $\mathrm{hH} 4$ & No binding & No binding \\
\hline
\end{tabular}

No binding: did not displace radioligand binding by $50 \%$ or more; NT: not tested; r: rat.

${ }^{a}$ From PDSP website: http://kidb.case.edu/pdsp.php.

levels $=0.22 \pm 0.04 \mathrm{pg} / 20 \mu \mathrm{l})$. As shown in Figure $4 \mathrm{a}$, mild handling stress increased mPFC DA levels again in a subsequent experiment, and intracortical M100907 pre- 
a

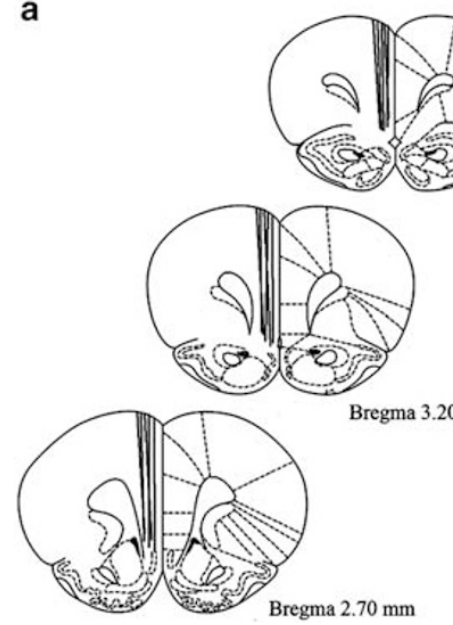

b

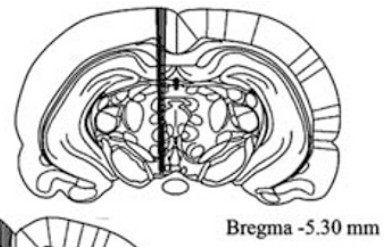

Bregma $3.70 \mathrm{~mm}$
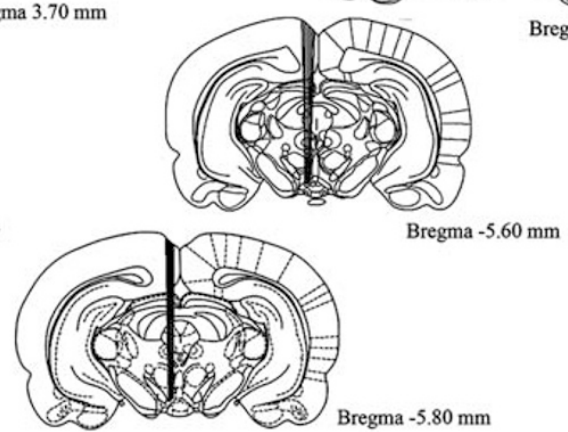

Figure I Microdialysis probe placements. (a) Schematic of representative probe placements in the medial prefrontal cortex. (b) Schematic of representative probe placements in the ventral tegmental area (VTA). The $1.0 \mathrm{~mm}$ active dialyzing surface of VTA probes was located at the most ventral extension of the probe.

treatment blocked this effect. A two-way ANOVA (drug group $\times$ time) of this data revealed a significant drug group $\times$ time interaction $(\mathrm{F}(6,102)=3.89, p=0.002)$. Indeed, mild handling significantly increased mPFC DA levels in vehicle-treated animals (time effect: $\mathrm{F}(6,36)=3.97$, $p=0.004, n=7$; Figure $4 \mathrm{a})$, but not in animals treated with intracortical $10 \mu \mathrm{M} \quad \mathrm{M} 100907 \quad(\mathrm{~F}(6,66)=1.306, p>0.05$, $n=12)$. As seen in Figure $4 \mathrm{~b}$, mild handling still increased mPFC DA levels in animals treated intracortically with $10 \mu \mathrm{M}$ SB 206553 (time effect: $\mathrm{F}(6,30)=5.37, p<0.001$, $n=6)$. The average basal levels of DA for these last three groups were $0.43 \pm 0.04 \mathrm{pg} / 20 \mu \mathrm{l}, n=25)$. Thus, cortical 5HT2A receptor blockade diminished stress-induced increases in $\mathrm{mPFC} \mathrm{DA}$, while $5-\mathrm{HT} 2 \mathrm{~B} / 2 \mathrm{C}$ receptor blockade did not.

\section{Effects of Risperidione on Stress-Induced DA Release in the $\mathrm{MPFC}$}

As shown in Figure 4c, 20 min handling stress again increased cortical DA levels in another group of rats, and local risperidone treatment blocked this effect. A two-way ANOVA (drug group $\times$ time) of this data revealed a significant drug group $\times$ time interaction $(\mathrm{F}(6,66)=3.68$, $p=0.003$ ) between these two groups. Indeed, vehicletreated rats showed significantly increased cortical DA efflux following handling (time effect: $\mathrm{F}(6,36)=6.27$, $p<0.001, n=7$; Figure $4 \mathrm{c}$ ), while animals pretreated locally with $10 \mu \mathrm{M}$ risperidone infusion did not $(\mathrm{F}(6,30)=0.21$, $p>0.05, n=6)$. The average basal levels of DA for this experiment were: $0.68 \pm 0.08 \mathrm{pg} / 20 \mu \mathrm{l}, n=13$.

\section{Cortical 5-HT2A Receptor Regulation of Mesocortical DA and Corticotegmental Glutamate}

Prefrontal cortical dopamine. A total of 26 rats were used for this experiment but, due to chromatographic problems with the DA assay, only 18 were used for the DA measurements (all 26 were used for the glutamate measurements, see below). Both the VTA and mPFC probes were functional in all 26 rats (see probe locations in Figure $1 \mathrm{~b}$ and $\mathrm{a}$, respectively). As seen in Figure 5a, systemic injections of DOI alone increased DA levels in the mPFC of rats, but this was not seen in animals cotreated with DOI and intracortical M100907. A two-way ANOVA (drug group $\times$ time) revealed that $\mathrm{mPFC}$ DA levels were significantly different between animals in the four treatment groups shown in Figure 5a (overall drug group effect: $\mathrm{F}(3,14)=3.79, p=0.035)$. Post hoc analysis indicated that rats treated with DOI alone showed significantly increased dialysate DA levels in the mPFC following treatment (time effect: $\mathrm{F}(6,18)=2.92, p=0.04, n=4)$. These subsided and returned to baseline levels by $2 \mathrm{~h}$ post injection. However, rats given DOI plus intracortical M100907 cotreatment showed the reverse $(\mathrm{F}(6,24)=2.77, p<0.03, n=5)$. Indeed, infusions of M100907 reversed the early DA increases by DOI and gradually diminished DA levels once the effect of DOI had subsided. There were no changes in DA levels in vehicle controls $(p>0.05, n=4)$. Although DA levels diminished in animals treated with intracortical M100907 alone (time effect: $\mathrm{F}(6,24)=3.47, p<0.01, n=5$ ), significant decreases relative to controls were only shown at two later time points across the $3 \mathrm{~h}$ treatment $\left(p^{\prime} s<0.05\right.$, see Figure 5a). Average basal levels for this experiment were $0.50 \pm 0.03 \mathrm{pg} / 20 \mu \mathrm{l}, n=18$.

VTA glutamate. The above four treatment groups also had an additional microdialysis probe located in the VTA, which allowed simultaneous assessment of VTA glutamate response to systemic DOI treatment. As can be seen in Figure 5b, systemic injections of DOI increased glutamate in the VTA and intracortical M100907 cotreatment reversed this effect. A two-way ANOVA (drug group $\times$ time) revealed that glutamate levels were significantly different between animals in the four treatment groups (overall drug group effect: $\mathrm{F}(3,22)=3.08, p=0.048)$. A marginal drug group $\times$ time interaction was also shown $(\mathrm{F}(18,132)=3.68, p=0.053)$. Indeed, systemic DOI significantly increased dialysate glutamate levels (time effect: $\mathrm{F}(6,36)=3.20, p=0.01, n=7$ ), while DOI plus intracortical M100907 cotreatment did not 

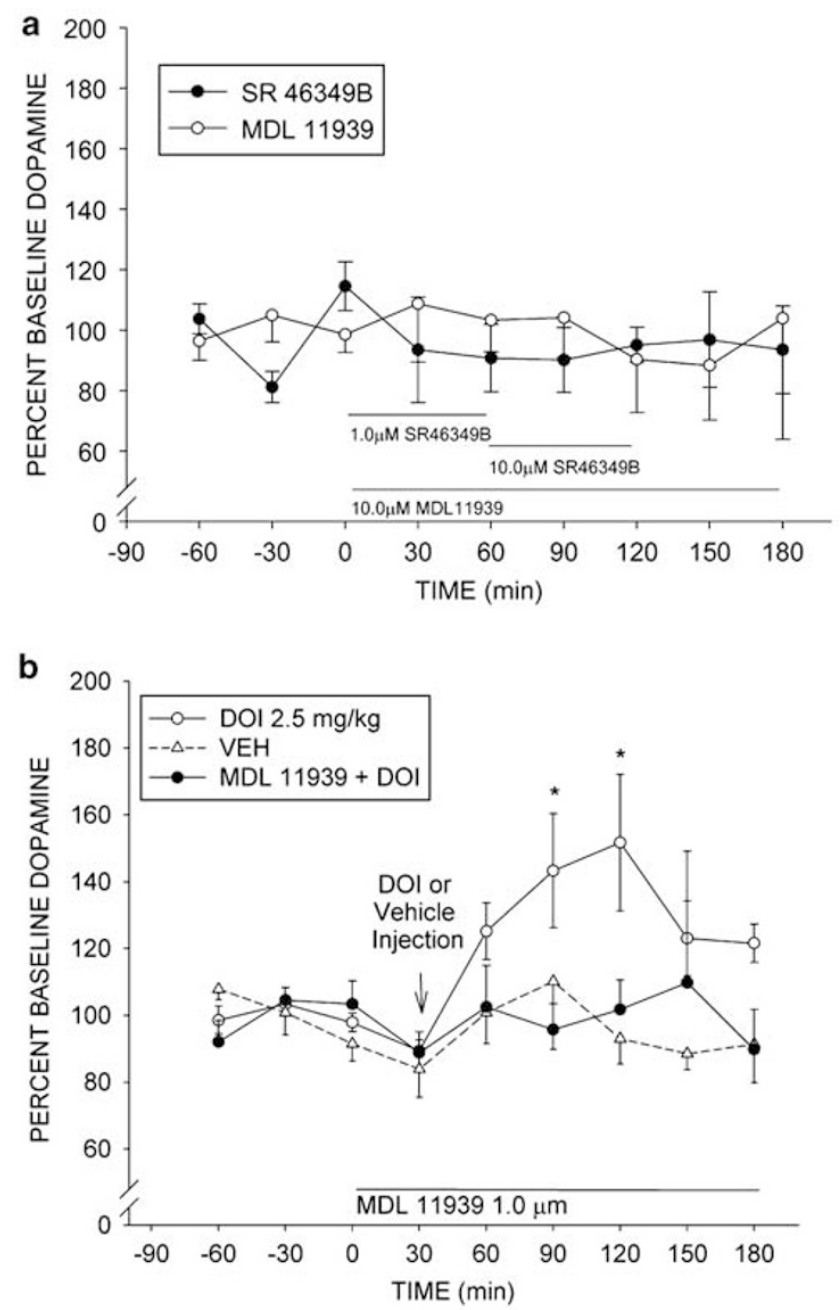

Figure 2 Effects of intracortical administration of the 5-HT2A antagonists SR 46349B and MDL 11,939 on DA release in the medial prefrontal cortex. (a) Intracortical infusions of SR 46349B or MDL I I,939 did not alter basal DA release. SR 46349B was infused at a $1.0 \mu \mathrm{M}$ concentration for I h followed by a $10.0 \mu \mathrm{M}$ concentration for I h. MDL II,939 (10 MM) was infused for $3 \mathrm{~h}$. (b) Intracortical infusions of MDL । I,939 blocked DOl-stimulated DA release. MDL I I,939 (I.0 $\mu \mathrm{M})$ was infused for $3 \mathrm{~h}$. Times of intracranial drug infusions are indicated by the lines. The 5 -HT2 agonist DOI (2.5 mg/kg s.c.) or vehicle was injected at time $30 \mathrm{~min}$ as indicated by the arrow. Data are the means \pm SEMs. $* 2<0.05$ relative to pre-drug baseline.

(see M100907+DOI group; $p>0.05, n=8$ ). Neither vehicle injections $(n=6)$ nor intracortical treatment with M100907 alone $(n=5)$ altered VTA dialysate glutamate concentrations. Average basal levels of glutamate were $0.45 \mathrm{ng} / 20 \mu \mathrm{l} \pm 0.03$, $n=26$. Thus, systemic DOI treatment increased VTA dialysate glutamate levels in the same group of animals that had shown DOI-induced DA increases above in the mPFC (see DOI group, Figure 5a vs b). Similarly, this effect was reversed by intracortical M100907 cotreatment.

\section{DISCUSSION}

The main finding of the present work is that blockade of prefrontocortical 5-HT2A receptors blocks the evoked

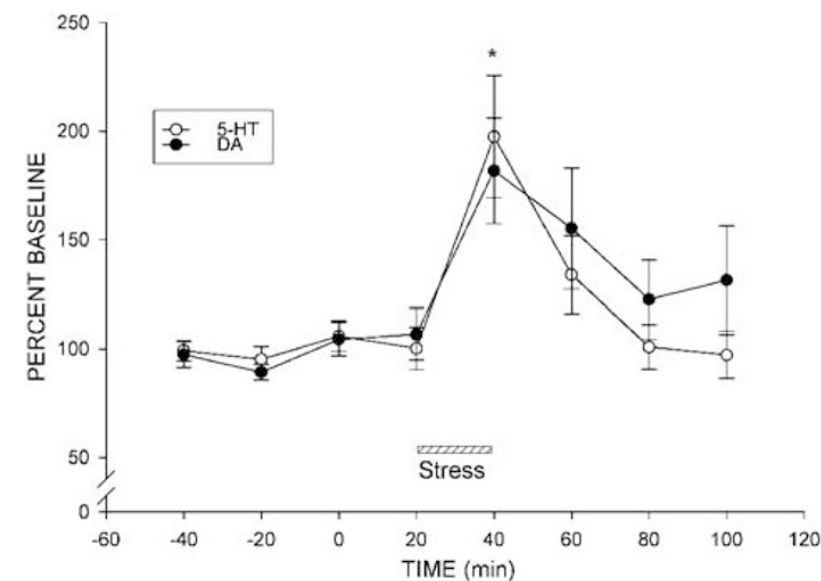

Figure 3 Stress increases 5-HT and DA release in the medial prefrontal cortex. Rats were gently handled for $20 \mathrm{~min}$ at the time indicated by the hatched bar. Data are the means \pm SEMs. ${ }^{*} p<0.05$ relative to pre-drug baseline.

release of DA from the mesocortical pathway. Importantly, 5-HT2A receptors could be implicated in regulating both pharmacologically and physiologically induced DA release. Intracortical perfusion with two different 5-HT2A antagonists, MDL 11,939 and M100907, attenuated DA efflux induced by the systemic administration of the 5-HT2 agonist DOI. These antagonists, as well as a third, SR 46349B, either did not alter basal dialysate DA or produced a small decrease, indicating that cortical 5-HT2A receptors do not generally modulate basal DA release in the mPFC. Rather, either the pharmacological stimulation of 5-HT2A receptors or their physiological stimulation by endogenous 5-HT may act to boost cortical DA levels. One situation in which this may occur is during stress. Stress is known to increase cortical 5-HT (Kawahara et al, 1993) and DA release (eg Abercrombie et al, 1989). Stress increased both neurochemicals in the present work (see Figure 3). Furthermore, antagonism of cortical 5-HT2A receptors blocked stress-induced DA efflux. In contrast, local inverse agonism of 5-HT2B/C receptors did not. Thus, endogeneous $5-\mathrm{HT}$, released during stress, appears to act on prefrontocortical 5-HT2A receptors to potentiate DA release.

These findings agree with, and build upon, recently published data. Gobert and Millan (1999) demonstrated that systemic administration of M100907 blocked DOI-induced DA release in the PFC. However, as mentioned previously, due to the robust pharmacology of M100907, it is not possible from these studies to unequivocally invoke 5-HT2A receptors in this response. Nonetheless, De Deurwaerdere and Spampinato (1999) observed that treatment with the 5-HT2A/2C antagonist SR 46539B also blocked phasic DA release in the nucleus accumbens. Systemic administration of M100907 attenuated fluoxetine-induced increases in cortical DA (Zhang et al, 2000). The current study compared the intracortical administration of several 5HT2A antagonists (M100907, MDL 11,939, risperidone) on phasic DA release in the mPFC. The findings indicate that 5-HT2A receptors regulate phasic mesocortical DA release, and that these receptors are localized, at least in part, to the medial PFC, where they are abundant. 

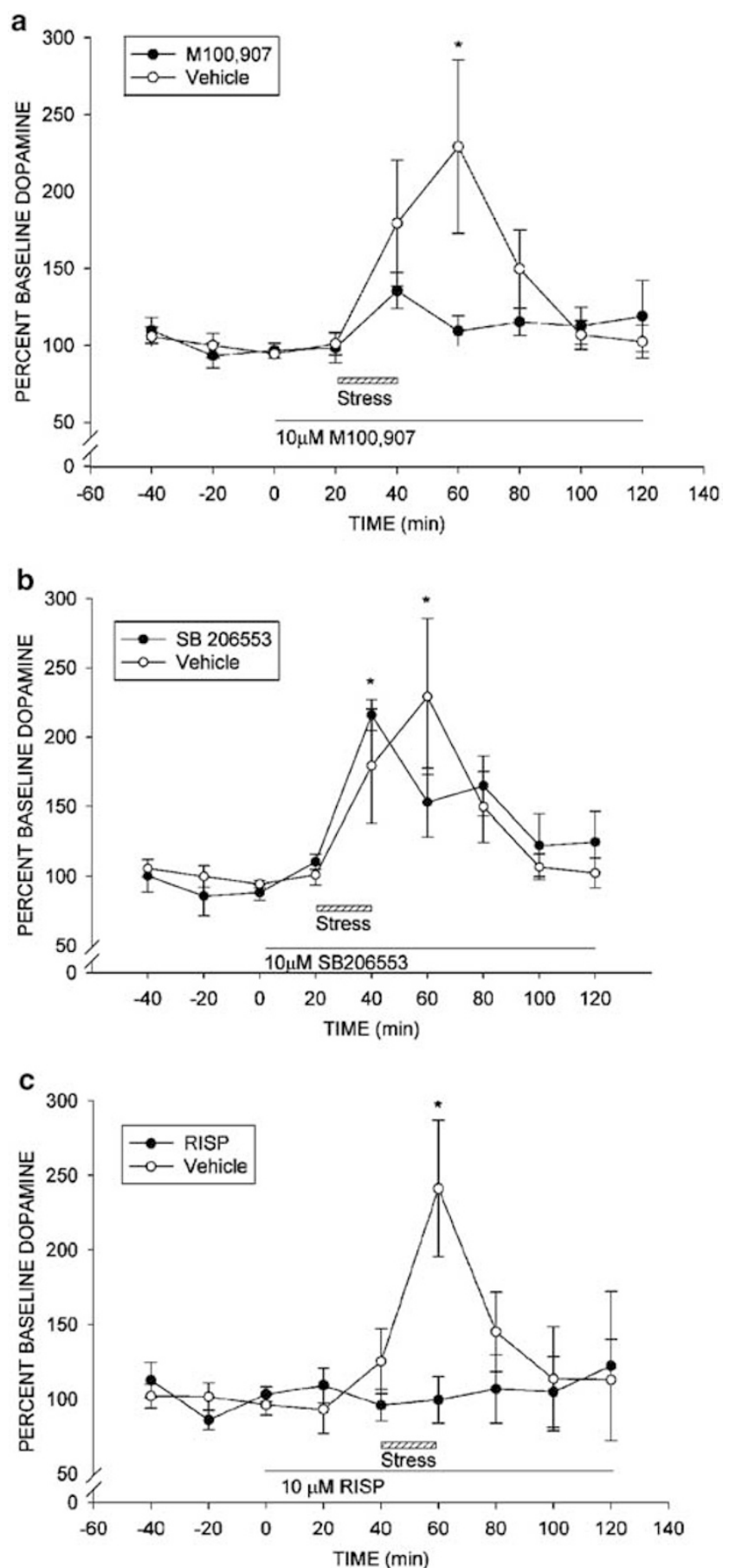

Figure 4 Effects of intracortical administration of 5-HT2 antagonists on acute stress-induced DA release in the medial prefrontal cortex. (a) Intracortical perfusion with MI00907 (10 $\mu \mathrm{M})$ blocked stress-induced DA efflux. (b) Intracortical perfusion with SB 206553 did not alter stress-induced DA efflux. (c) Intracortical perfusion with risperidone $(10 \mu \mathrm{M}, \mathrm{RISP})$ blocked stressinduced DA efflux. Drugs were infused for $2 \mathrm{~h}$ as indicated by the lines. Rats were gently handled for $20 \mathrm{~min}$ at the times indicated by the hatched bars. In contrast to intracortical MI00907 and SB 206553 pretreatment, risperidone infusion began 40 min before handling stress was applied to be sure that $\mathrm{mPFC}$ DA levels were stable under the treatment prior to stress application (see text). Data are the means \pm SEMs. $* 0<0.05$ relative to pre-drug baseline.

The present work demonstrates that M100907, MDL 11,939, and SR 46349B are all potent 5-HT2A ligands, with an order of potency SR 46349B $>$ M100907 > MDL 11,939.
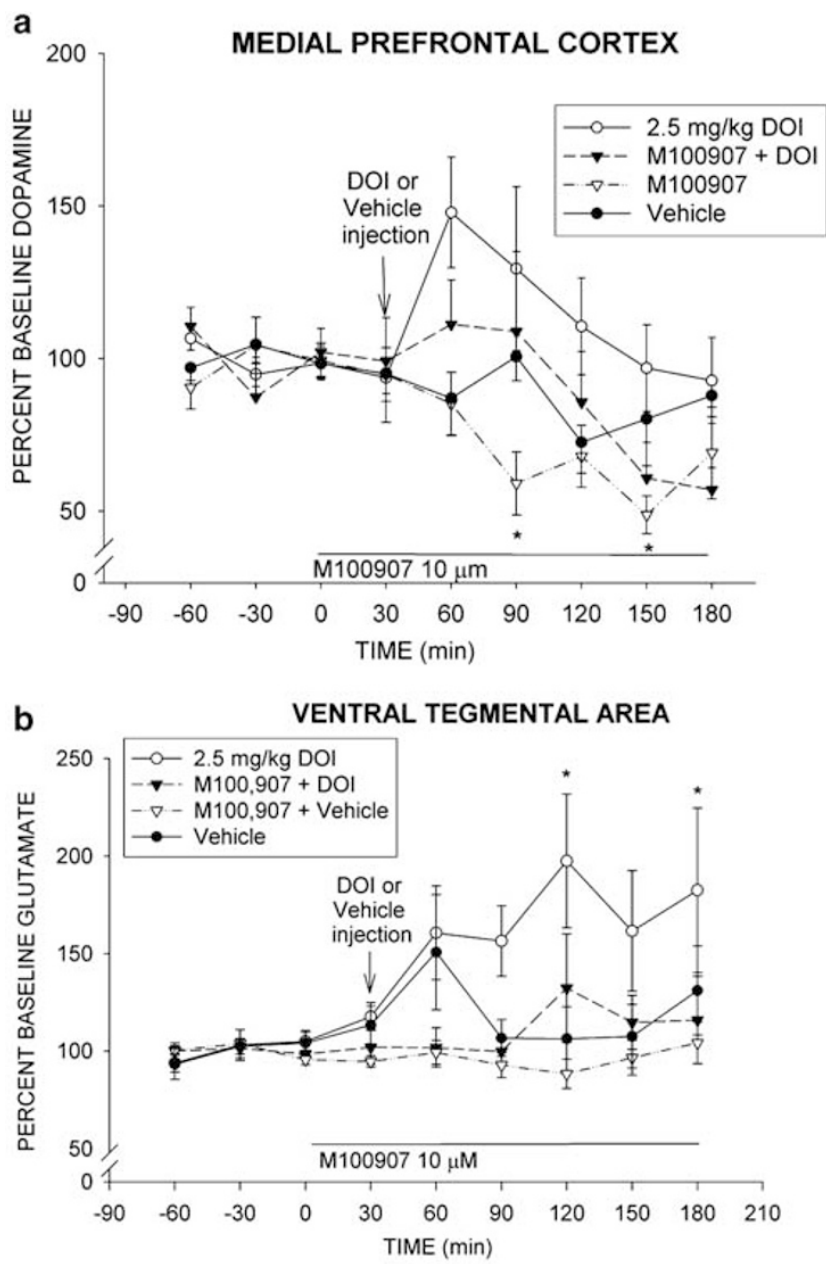

Figure 5 Effects of systemic DOI and intracortical MI00907 on transmitter release in the medial prefrontal cortex and VTA using dualprobe microdialysis. (a) Intracortical infusions of MI00907 blocked DOIstimulated DA release in the medial prefrontal cortex. MI00907 (I $0.0 \mu \mathrm{M})$ was infused for $3 \mathrm{~h}$ as indicated by the line. DOI ( $2.5 \mathrm{mg} / \mathrm{kg}$ s.c.) or vehicle was injected at time $30 \mathrm{~min}$ as indicated by the arrow. (b) Intracortical infusions of MI00907 blocked DOl-stimulated glutamate release in the VTA. MI 00907 ( $10.0 \mu \mathrm{M})$ was infused for $3 \mathrm{~h}$ as indicated by the line. DOI ( $2.5 \mathrm{mg} / \mathrm{kg}$ s.c.) or vehicle was injected at time $30 \mathrm{~min}$ as indicated by the arrow. Data are the means \pm SEMs. $* p<0.05$ relative to pre-drug baseline

However, SR 46349B is much less selective (only eight-fold selectivity for the 5-HT2A vs the 5-HT2C receptor, see Table 1). Recent work has consistently shown that the systemic administration of M100907 alone does not alter basal mPFC DA levels over a wide range of doses (eg Bonaccorso et al, 2002). While moderate doses (1-3 mg/ $\mathrm{kg}$ ) of SR 46349B also did not alter DA in the mPFC or nucleus accumbens, a higher dose $(10 \mathrm{mg} / \mathrm{kg})$ increased cortical DA efflux (Bonaccorso et al, 2002). This increase may reflect the relative nonselectivity of SR $46349 \mathrm{~B}$ and may have resulted from actions on 5-HT2C receptors $\left(K_{\mathrm{i}}=\right.$ 8.24, see Table 1). Other work has shown that systemic administration of 5-HT2C antagonists or inverse agonists increases cortical DA efflux (Millan et al, 1998; Gobert et al, 2000; Pozzi et al, 2002). In contrast to systemic administration, we clearly show that intracortical SR 46349B, as well as MDL 11,939 do not alter basal DA levels in the mPFC. 
Cortical administration of the 5-HT2B/2C inverse agonist, SB206553, also does not alter basal mPFC DA levels (Alex et al, 2005). Thus, increases in cortical DA efflux by systemic application of drugs with 5-HT2A or 5-HT2C antagonist properties is not due to their interaction with cortical 5-HT2A or 5-HT2C receptors. Interestingly, intracortical infusions of M100907 slightly decreases basal DA release (Pehek et al, 2001; current work, see Figure 5). The equally potent 5-HT2A antagonist MDL 11,939 did not diminish basal DA levels in this study, and it is even more preferentially selective for the 5-HT2A vs 5-HT2C receptors than M100907 (see Table 1). The moderate affinity of M100907 for the 5-HT2C receptor $\left(K_{\mathrm{i}}=88.0 \mathrm{nM}\right.$, see Table 1$)$ would not induce this decrease (Alex et al, 2005). Possibly the slight change by M100907, and absence by MDL 11,939, is due to their differential $\alpha 1$ adrenergic receptor-binding properties $\left(K_{\mathrm{i}}=128 v\right.$ s 1800 , respectively; see Table 1$)$. Local antagonism of adrenergic $\alpha 1$ receptors diminish DA levels in the mPFC (Pan et al, 2004). Nonetheless, selective antagonism of cortical 5-HT2A receptors clearly does not increase basal DA efflux in the mPFC.

In contrast to studies employing the administration of 5-HT2A antagonists alone, the combined, systemic administration of D2 and 5-HT2A receptor antagonists results in a potentiation of DA release (Westerink et al, 2001; Liegeois et al, 2002). Although the exact mechanism is not clear, evidence has been provided that this effect may be mediated by a combined potent $5-\mathrm{HT} 2 \mathrm{~A}$ and relatively weak D2 receptor effect interacting with 5 -HT1A receptor-regulated brain mechanisms (Bonaccorso et al, 2002; Ichikawa et al, 2001). This potentiation may also result from the actions of drugs on DA cells in the VTA. We have shown that many VTA DA neurons express 5-HT2A receptors (Nocjar et al, 2002). It is clear from the present work that selective antagonism of cortical 5-HT2A receptors does not increase basal DA efflux but, in fact, blocks evoked DA release.

Electrophysiological studies indicate that stimulation of mPFC 5-HT2A receptors increases pyramidal cell activity (Aghajanian and Marek, 1997), suggesting that 5-HT2A receptor agonism may increase the activity of corticotegmental glutamatergic projection neurons. Indeed, systemic administration of the 5-HT2 agonist DOI increased glutamate efflux in the VTA in the present study. Infusions of M100907, directly into the mPFC, blocked this increase, implying that the relevant 5HT2A receptors were localized in the mPFC. In the same animals, treatment with DOI increased mPFC DA efflux and this was also blocked by intracortical administration of M100907. Thus, systemic DOI increased glutamate in the VTA and DA in the MPFC, in the same animals, through a cortical 5-HT2A receptor mechanism. Interestingly, Artigas and co-workers recently found that either the systemic or intracortical administration of DOI increased the activity of VTA mesocortical DA neurons (Bortolozzi et al, 2004). This was blocked by the intracortical administration of 5-HT2A antagonists. Thus, both studies suggest that regulation of mesocortical DA by cortical 5-HT2A receptors may involve a polysynaptic neural circuit. A subset of cortical pyramidal neurons synapse on mesocortical DA cell bodies in the VTA (Sesack and Pickel, 1992; Carr and Sesack, 2000), and the majority of 5-HT2A receptors in the MPFC are localized to the apical dendrites of pyramidal cells (Willins et al, 1987; Jakab and
Goldman-Rakic, 1998; Miner et al, 2003). Other potential circuits would be indirect projections from the mPFC to the VTA. A role for presynaptic regulation of DA release also cannot be discounted. 5-HT2A receptors have been recently found in the mPFC on presynaptic axons and varicosities that expressed morphological features of monoamine axons (Miner et al, 2003). We have previously shown that intracortical infusions of M100907 block local $\mathrm{K}^{+}$-stimulated DA release in the mPFC (Pehek et al, 2001). Since high $\mathrm{K}^{+}$stimulates transmitter release by depolarizing nerve terminals, it is possible that M100907 may have acted to block DA efflux through actions on 5-HT2A receptors localized presynaptically on DA terminals.

The present work demonstrates that mPFC 5-HT2A receptors do not generally modulate basal cortical DA release. Rather, endogenous 5-HT, released phasically, appears to activate cortical 5-HT2A receptors to subsequently stimulate DA release. Acute stress increases the release of cortical 5-HT (Figure 3; Kawahara et al, 1993) and DA (eg Abercrombie et al, 1989; Kawahara et al, 1999). The current findings demonstrate that blockade of cortical 5HT2A receptors attenuates mild stress-induced DA release: this is the first evidence that cortical 5-HT2A antagonism blocks physiologically induced DA efflux in the mPFC. This effect did not involve other 5-HT2 family receptors, since the 5-HT2B/C inverse agonist SB 206553 did not alter stressinduced cortical DA. Thus, physiologically induced phasic release of DA in the $\mathrm{mPFC}$ depends, at least partially, on activation of local 5-HT2A receptors in the area. Interestingly, behavioral deficits in prepulse inhibition, which are known to be regulated in the $\mathrm{mPFC}$, are reversed by M100907 in animals with genetically elevated synaptic levels of DA (Barr et al, 2004; Gainetdinov et al, 1999). Thus, its been suggested that 5-HT2A antagonists may be useful in the treatment of conditions characterized by chronic, elevated dopaminergic tone (Gainetdinov et al, 1999). Indeed, a recent large-scale placebo-controlled clinical trial with SR46349B demonstrated its ability to treat schizophrenia (Meltzer et al, 2004), and we have shown in this study that it has a high affinity for the 5-HT2A receptor. M100907 has a similar affinity for the 5-HT2A receptor as SR46349B (see Table 1), but was minimally effective in treating two schizophrenia patients in a recent report (Talvik-Lotfi et al, 2000), although the authors stress that efficacy shown with a sample of two is clearly not conclusive (Talvik-Lotfi et al, 2000). Nonetheless, SR46349B, in contrast to M100907, also has high affinity for the 5-HT2C receptor (see Table 1). Many atypical antipsychotic drugs that bind to the 5-HT2A receptor also show moderate to potent 5-HT2C receptor-binding properties (Roth et al, 2004), suggesting that efficacy may involve some combination of effect between these receptors. However, our current findings with SB206553 indicate that intracortical 5-HT2C antagonism, without 5-HT2A antagonism, does not alter phasic DA release in the $\mathrm{mPFC}$.

In the present study, intracortical infusions of the atypical antipsychotic drug risperidone also blocked stress-induced DA release. This effect may have been mediated, at least partially, by blockade of local 5-HT2A receptors, since cortical M100907 induced a similar effect. It is unknown whether cortical risperidone infusion, as used in the current work, would increase 5-HT levels in the mPFC as has been 
shown with systemic risperidone treatment (Ichikawa et al, 1998; Hertel et al, 1996; although see Zhang et al, 2000; Ojima et al, 2004). If so, other non-5-HT2 serotonin receptors could be implicated in this stress effect of risperidone. 5-HT2A and 5-HT1A receptors locally modulate 5-HT in the mPFC (Martin-Ruiz et al, 2001). However, risperidone is a 5-HT2A antagonist and cortical 5-HT2A antagonist treatment does not increase 5-HT locally (Martin-Ruiz et al, 2001). Also, risperidone has low affinity for the 5-HT1A receptor $\left(K_{\mathrm{i}}=250 \mathrm{nM}\right.$; http://kidb.case.edu/ pdsp.php).

Like other atypical antipsychotic drugs, risperidone has a robust pharmacology, binding to many biogenic amine receptors (Roth et al, 2004), including 5-HT2A-serotonin and D2-dopamine receptors. Indeed, this combination of properties may explain why the systemic administration of higher doses $(1 \mathrm{mg} / \mathrm{kg})$ of risperidone produces increases in mPFC DA efflux (Hertel et al, 1996; Kuroki et al, 1999; Zhang et al, 2000). Lower doses of risperidone $(0.004 \mathrm{mg} /$ $\mathrm{kg}$ ), like M100907, do not alter cortical DA efflux (Westerink et al, 1998, 2001). These lower doses may result in more selective effects on 5-HT2A receptors and are closer to the range employed clinically. Studies suggest that risperidone may not increase prefrontal DA release clinically in schizophrenia patients (Miller et al, 2001; Molina et al, 2003).

The possibility exists that $5-\mathrm{HT} 2 \mathrm{~A}$ receptor blockade may have clinical utility in the treatment of conditions linked to a phasic hyperactivity of DA systems. Preclinical studies indicate that supranormal DA activity in the $\mathrm{MPFC}$ may be maladaptive. DA released during stress (Arnsten and Goldman-Rakic, 1998) or supranormal D1 receptor stimulation (Zahrt et al, 1997; Goldman-Rakic et al, 2000) both impair cognitive function. Phasic PFC DA function appears to be magnified in schizophrenia patients (Laruelle et al, 1999) and basal cortical DA function possibly diminished (see Molina et al, 2005a, b). Indeed, PFC D1 receptors are upregulated in these patients (Abi-Dargham et al, 2002). Phasic release of DA by stress or drugs under these conditions would induce a magnified effect. Indeed, schizophrenic patients are more sensitive to stress and more sensitive to the psychotic and cognitive impairing effects of amphetamine (Abi-Dargham et al, 1998; Breier et al, 1997; Laruelle et al, 1999). Stress is also known to exacerbate schizophrenic symptoms. Thus, the clinical efficacy of risperidone, and other atypical antipsychotic drugs, which block 5-HT2A receptors, could be at least partially due to their ability to diminish the effect of stress on $\mathrm{mPFC}$ function in these patients.

However, it should be noted that a large body of evidence indicates that reduced DA tone in the mPFC is associated with impaired cognition (Jentsch and Roth, 1999). Indeed, the cognitive deficits and negative symptoms of schizophrenia have been associated with basal dopaminergic hypoactivity in the PFC (Weinberger, 1987). Therefore, it is likely that an optimal balance of DA tone in the PFC is essential for normal cortical function (Williams and Goldman-Rakic, 1995). Highly efficacious antipsychotic drugs may have receptor-binding properties that increase basal mesocortical DA release while decreasing evoked DA release. In fact, it has been proposed that schizophrenia may be related to deficits in both tonic and phasic DA release (Grace, 1991). Interestingly, intracortical administration of 5-HT2A or 5-HT2C receptor antagonists do not alter basal mPFC DA (Pehek et al, 2001; Alex et al, 2005; current work). However, systemic administration of selective 5-HT2C anatagonists increase basal DA levels in the mPFC (see Di Matteo et al, 2001), while the selective 5HT2A receptor antagonist M100907 does not (eg Bonaccorso et al, 2002). In contrast, intracortical M100907 blocks phasic DA release in the mPFC, while selective 5-HT2C antagonists do not (Pehek et al, 2001, current work). Thus, the binding affinity of atypical antipsychotic treatments to both of these receptors may be particularly important (Roth et al, 2004; Meltzer et al, 2003). Indeed, their efficacy could be due to their ability to increase basal cortical DA levels through 5-HT2C receptors located outside the PFC, and to their ability to diminish phasic cortical DA levels through their interaction with 5-HT2A receptors located within the PFC. An important area of future work would be to determine whether other atypical antipsychotic drugs that increase basal mPFC DA levels when administered systemically to animals (Meltzer et al, 2003) would also locally diminish mPFC DA release induced phasically by stress. Indeed, recent PET studies suggest that the highly efficacious drug clozapine may increase basal DA function in the PFC of schizophrenia patients (Cohen et al, 1997; Lahti et al, 2003; Molina et al, 2005a; Potkin et al, 2003). However, one exposure to amphetamine, which phasically increases cortical DA function in these patients, worsens their psychosis (Laruelle et al, 1999).

In summary, intracortical administration of two 5-HT2A antagonists blocked mesocortical DA release induced by the systemic administration of the 5-HT2 agonist DOI. Treatment with DOI also increased glutamate efflux in the VTA and DA release in the $\mathrm{mPFC}$ of the same animals; effects blocked by cortical 5-HT2A receptor antagonism. These results indicate that stimulation of cortical 5-HT2A receptors facilitates mesocortical DA release. They suggest that this effect may be mediated by the activation of corticotegmental glutamatergic projections that synapse on mesocortical DA neurons, although further work must be carried out to test this hypothesis. Importantly, blockade of cortical 5-HT2A receptors or local perfusion with the antipsychotic drug risperidone also attenuated mild stressinduced DA release in the PFC. Thus, cortical 5-HT2A receptors modulate the evoked release of DA in the $\mathrm{mPFC}$, including that which is induced physiologically by stress. It is well known that schizophrenia is exacerbated by stress. Thus, the clinical efficacy of risperidone and other atypical antipsychotic treatments may be due, at least partially, to their ability to diminish stress-induced effects in the mPFC.

\section{ACKNOWLEDGEMENTS}

This work was supported by a MERIT Review award from the Department of Veterans Affairs, MH 52220 from NIH, and a grant from Janssen Extramural Research Foundation to EAP. BLR was supported by KO2MH01366, MH57635, MH61887, and the NIMH Psychoactive Drug Screening Program. We thank Marion Merrell Dow, Janssen Pharmaceutica, SmithKline and Beecham, and Sanofi Recherche for their generous contributions of drugs. We also thank Bobbi 
Kirkbride and Indrani Sivagnaniar for their excellent technical assistance.

\section{REFERENCES}

Abercrombie ED, Keefe KA, DiFrischia DS, Zigmond MJ (1989). Differential effect of stress on in vivo dopamine release in striatum, nucleus accumbens, and medial prefrontal cortex. J Neurochem 52: 1655-1658.

Abi-Dargham A, Gil R, Krystal J, Baldwin RM, Seibyl JP, Bowers M et al (1998). Increased striatal dopamine transmission in schizophrenia: confirmation in a second cohort. Am J Psychiatry 155: 761-767.

Abi-Dargham A, Mawlawi O, Lombardo I, Gill R, Martinez D, Huang $\mathrm{Y}$ et al (2002). Prefrontal dopamine D1 receptors and working memory in schizophrenia. J Neurosci 22: 3708-3719.

Aghajanian G, Marek G (1997). Serotonin induces excitatory postsynaptic potentials in apical dendrites of neocortical pyramidal cells. Neuropharmacology 36: 589-599.

Alex KD, Yavanian GJ, McFarlane HG, Pluto CP, Pehek EA (2005). Modulation of dopamine release by striatal 5-HT2C receptors. Synapse 55: 242-251.

Arnsten AFT, Goldman-Rakic PS (1998). Noise stress impairs prefrontal cortical cognitive function in monkeys. Arch Gen Psychiatry 55: 362-368.

Azmitia EC, Segal M (1978). An autoradiographic analysis of the differential ascending projections of the dorsal and median raphe nuclei in the rat. J Compr Neurol 179: 641-668.

Barr AM, Lehmann-Masten V, Paulus M, Gainetdinov RR, Caron MG, Geyer MA (2004). The selective serotonin-2A receptor antagonist M100907 reverses behavioral deficits in dopamine transporter knockout mice. Neuropsychopharmacology 29: 221-228.

Beart PM, McDonald D (1982). 5-Hydroxytryptamine and 5hydroxytryptaminergic-dopaminergic interactions in the ventral tegmental area of rat brain. J Pharm Pharmacol 34: 591-593.

Bonaccorso S, Meltzer H, Li Z, Dai J, Alboszta A, Ichikawa J (2002). SR46349-B, a 5-HT(2A/2C) receptor antagonist, potentiates haloperidol-induced dopamine release in rat medial prefrontal cortex and nucleus accumbens. Neuropsychopharmacology 27: 430-441.

Bortolozzi A, az-Mataix LD, Scorza C, Celada P, Artigas F (2004). Atypical antipsychotics modulate a prefrontal $5-\mathrm{HT}_{2 \mathrm{~A}}$ receptormediated activation of the mesocortical dopaminergic pathway. Abstract Viewer/Itinerary Planner Washington, DC: Society for Neuroscience Program No. 45.10.

Breier A, Su TP, Saunders R, Carson RE, Kolachana BS, de Bartolomeis A et al (1997). Schizophrenia is associated with elevated amphetamine-induced synaptic dopamine concentrations: evidence from a novel positron emission tomography method. Proc Natl Acad Sci USA 94: 2569-2574.

Carr DB, Sesack SR (2000). GABA-containing neurons in the rat ventral tegmental area project to the prefrontal cortex. Synapse 38: 114-123.

Cohen RM, Nordahl TE, Semple WE, Andreason P, Litman RE, Pickar D (1997). The brain metabolic patterns of clozapine- and fluphenazine-treated patients with schizophrenia during a continuous performance task. Arch Gen Psychiatry 54: 481-486.

Davies MA, Compton-Toth BA, Hufeisen SJ, Meltzer HY, Roth BL (2005). The highly efficacious actions of $N$-desmethylclozapine at muscarinic receptors are unique and not a common property of either typical or atypical antipsychotic drugs: is $\mathrm{M}(1)$ agonism a pre-requisite for mimicking clozapine's actions? Psychopharmacology (Berl) 178: 451-460.

De Deurwaerdere P, Spampinato U (1999). Role of serotonin2A and serotonin $2 \mathrm{~B} / 2 \mathrm{C}$ receptor subtypes in the control of accumbal and striatal dopamine release elicited in vivo by dorsal raphe nucleus electrical stimulation. J Neurochem 73: 1033-1042.

Di Matteo V, De Blasi A, Di Giulio C, Esposito E (2001). Role of 5 -HT2C receptors in the control of central dopamine function. Trends Pharmacol Sci 22: 229-232.

Doherty MD, Pickel VM (2000). Ultrastructural localization of the serotonin2A receptor in dopaminergic neurons in the ventral tegmental area. Brain Res 864: 176-185.

Donzanti BA, Yamamoto BK (1988). An improved and rapid HPLC-ED method for the isocratic seperation of amino acid neurotransmitters from brain tissue and microdialysis perfusates. Life Sci 43: 913-922.

Feenstra MGP, Botterblom MHA (1996). Rapid sampling of extracellular dopamine in the rat prefrontal cortex during food consumption, handling and exposure to novelty. Brain Res 742: $17-24$.

Gainetdinov RR, Jones SR, Caron MG (1999). Functional hyperdopaminergia in dopamine transporter knock-out mice. Biol Psychiatry 46: 303-311.

Gobert A, Millan MJ (1999). Serotonin (5-HT)2A receptor activation enhances dialysate levels of dopamine and noradrenaline, but not 5-HT, in the rat frontal cortex of freely-moving rats. Neuropharmacology 38: 315-317.

Gobert A, Rivet J, Lejeune F, Newman-Tancredi A, AdhumeauAuclair A, Nicolas J et al (2000). Serotonin2C receptors tonically suppress the activity of mesocortical dopaminergic and adrenergic, but not serotonergic, pathways: a combined dialysis and electrophysiological analysis in the rat. Synapse 36: 205-221.

Goldman-Rakic PS, Muly III EC, Williams GV (2000). D1 receptors in prefrontal cells and circuits. Brain Res Rev 31: 295-301.

Gomeza J, Mary S, Brabet I, Parmentier M, Restituito S, Bockaert J et al (1996). Coupling of metabotropic glutamate receptors 2 and 4 to $G$ alpha $15, G$ alpha 16 , and chimeric $G$ alpha $q / i$ proteins: characterization of new antagonists. Mol Pharmacol 50: 923-930.

Grace AA (1991). Phasic versus tonic dopamine release and the modulation of dopamine system responsivity: a hypothesis for the etiology of schizophrenia. Neuroscience 41: 1-24.

Hertel P, Nomikos GG, Iurlo M, Svensson TH (1996). Risperidone: regional effects in vivo on release and metabolism of dopamine and serotonin in the rat brain. Psychopharmacology 124: 74-86.

Ichikawa J, Ishii H, Bonaccorso S, Fowler WL, O'Laughlin IA, Meltzer HY (2001). 5-HT2A and D2 receptor blockade increases cortical DA release via 5-HT1A receptor activation: a possible mechanism of atypical antipsychotic-induced cortical dopamine release. J Neurochem 76: 1521-1531.

Ichikawa J, Kuroki T, Dai J, Meltzer HY (1998). Effect of antipsychotic drugs on extracellular serotonin levels in rat medial prefrontal cortex and nucleus accumbens. Eur $J$ Pharmacol 351: 163-171.

Inglis FM, Moghaddam B (1999). Dopaminergic innervation of the amygdala is highly responsive to stress. J Neurochem 72: 1088-1094.

Jakab RL, Goldman-Rakic PS (1998). 5-Hydroxytryptamine(2A) serotonin receptors in the primate cerebral cortex: possible site of action of hallucinogenic and antipsychotic frugs in pyramidal cell apical dendrites. Proc Natl Acad Sci USA 95: 735-740.

Jentsch JD, Roth RH (1999). The neuropsychopharmacology of phencyclidine: from NMDA receptor hypofunction to the dopamine hypthesis of schizophrenia. Neuropsychopharmacology 20: 201-225.

Kawahara H, Yshidda M, Hideyasu Y, Masakatsu N, Masatoshi T (1993). Psychological stress increases serotonin release in the rat amygdala and prefrontal cortex assessed by in vivo microdialysis. Neurosci Lett 162: 81-84.

Kawahara Y, Kawahara H, Westerink BHC (1999). Comparison of effects of hypotension and handling stress on the release of noradrenaline and dopamine in the locus coeruleus and medial 
prefrontal cortex of the rat. Naunyn-Schmiedeberg's Arch Pharmacol 360: 42-49.

Kozikowski A, Steensma D, Araldi GL, Tuckmantel W, Wang S, Pshenichkin S et al (1998). Synthesis and biology of the conformationally restricted ACPD analogue, 2-aminobicyclo[2.1.1.]hexane-2,5-dicarboxylic acid-I, a potent mGluR agonist. J Med Chem 41: 1641-1650.

Kuroki T, Meltzer HY, Ichikawa J (1999). Effects of antipsychotic drugs on extracellular dopamine levels in rat medial prefrontal cortex and nucleus accumbens. J Pharmacol Exp Ther 288: 774-781.

Lahti AC, Holcomb HH, Weiler MA, Medoff DR, Tamminga CA (2003). Functional effects of antipsychotic drugs: comparing clozapine with haloperidol. Biol Psychiatry 53: 601-608.

Laruelle M, Abi-Dargham A, Gil R, Kegeles L, Innis R (1999). Increased dopamine transmission in schizophrenia: relationship to illness phases. Biol Psychiatry 46: 56-72.

Liegeois J-F, Ichikawa J, Meltzer HY (2002). 5-HT2A receptor antagonism potentiates haloperidol-induced dopamine release in rat medial prefrontal cortex and inhibits that in the nucleus accumbens in a dose-dependent manner. Brain Res 947: 157-165.

Martin-Ruiz R, Puig VM, Celada P, Shapiro DA, Roth BL, Mengod $\mathrm{G}$ et al (2001). Control of serotonin function in medial prefrontal cortex by serotonin-2A receptors through a glutamate-dependent mechanism. J Neurosci 21: 9856-9866.

Meltzer HY (1989). Clinical studies on the mechanism of action of clozapine: the dopamine-serotonin hypothesis of schizophrenia. Psychopharmacology 99: S18-S27.

Meltzer HY, Arvanitis L, Bauer D, Rein W (2004). Placebocontrolled evaluation of four novel compounds for the treatment of schizophrenia and schizoaffective disorder. Am J Psychiatry 161: 975-984.

Meltzer HY, Li Z, Kaneda Y, Ichikawa J (2003). Serotonin receptors: their key role in drugs to treat schizophrenia. Prog Neuro-Psychopharm Biol Psychiatry 27: 1159-1172.

Millan MJ, Dekeyne A, Gobert A (1998). Serotonin (5-HT)2C receptors tonically inhibit dopamine (DA) and noradrenaline (NA), but not 5-HT, release in the frontal cortex in vivo. Neuropharmacology 37: 953-955.

Miller DD, Andreasen NC, O'Leary DS, Watkins GL, Boles Ponto LL, Hichawa RD (2001). Comparison of the effects of risperidone and haloperidol on regional cerebral blood flow in schizophrenia. Biol Psychiatry 49: 704-715.

Miner LAH, Backstrom JR, Sanders-Bush E, Sesack (2003). Ultrastructural localization of serotonin $2 \mathrm{~A}$ receptors in the middle layers of the rat prelimbic prefrontal cortex. Neuroscience 116: 107-117.

Moghaddam B, Bunney BS (1990). Acute effects of typical and atypical antipsychotic drugs on the release of dopamine from prefrontal cortex, nucleus accumbens, and striatum of the rat: an In Vivo Microdialysis Study. J Neurochem 54: 1755-1760.

Molina V, Gispert JD, Reig S, Sanz J, Pascau J, Santos A et al (2005a). Cerebral metabolic changes induced by closapine in schizophrenia and related to clinical improvement. Psychopharmcology 178: 17-26.

Molina V, Gispert JD, Reig S, Sanz J, Pascau J, Santos A et al (2003). Cerebral metabolism and risperidone treatment in schizophrenia. Schizophr Res 60: 1-7.

Molina V, Sanz J, Sarramea F, Benito C, Palomo T (2005b). Prefrontal atrophy in first episodes of schizophrenia associated with limbic metabolic hyperactivity. J Psychiat Res 39: 117-127.

Nocjar C, Roth BL, Pehek EA (2002). Localization of 5- $\mathrm{HT}_{2 \mathrm{~A}}$ receptors on dopamine cells in subnuclei of the midbrain A10 cell group. Neuroscience 111: 163-176.

Obrenovitch TP, Urenjak J, Richards DA, Ueda Y, Curzon G, Symon L (1993). Extracellular neuroactive amino acids in the rat striatum during ischaemia: comparison between penumbral conditions and ischaemia with sustained anoxic depolarisation. J Neurochem 61: 178-186.

Ojima T, Ito C, Sakurai E, Sakurai E, Watanabe T, Yanai K (2004). Effects of serotonin-dopamine antagonists on prepulse inhibition and neurotransmitter contents in the rat cortex. Neurosci Lett. 366: 130-134.

Pan WHT, Yang S-Y, Lin S-K (2004). Neurochemical interaction between dopaminergic and noradrenergic neurons in the medial prefrontal cortex. Synapse 53: 44-52.

Paxinos G, Watson C. (1998). The Rat Brain in Stereotaxic Coordinates. Academic Press: New York.

Pehek EA, McFarlane EA, Maguschak K, Price B, Pluto CP (2001). M100,907, a selective $5-\mathrm{HT}_{2 \mathrm{~A}}$ antagonist, attenuates dopamine release in the rat medial prefrontal cortex. Brain Res 888: 51-59.

Pehek EA, Yamamoto BK (1994). Differential effects of locally administered clozapine and haloperidol on dopamine efflux in the rat prefrontal cortex and caudate-putamen. $J$ Neurochem 63 : 2118-2124.

Potkin SG, Basile VS, Jin Y, Masellis M, Badri F, Keator D et al (2003). D1 receptor alleles predict PET metabolic correlates of clinical response to clozapine. Mol Psychiatry 8: 109-113.

Pozzi L, Acconcia S, Ceglia I, Invernizzi RW, Smamanin R (2002). Stimulation of 5-hydroxytryptamine $(5 \mathrm{HT} 2 \mathrm{C})$ receptors in the ventrotegmental area inhibits stress-induced but not basal dopamine release in the rat prefrontal cortex. I Neurochem 82: $93-100$.

Roth B, Hamblin M, Ciaranello R (1991). Developmental regulation of 5-HT2 and 5-HT1c mRNA and receptor levels. Brain Res Dev Brain Res 58: 51-58.

Roth B, Meltzer H, Khan N (1998). Binding of typical and atypical antipsychotic drugs to multiple neurotransmitter receptors. Adv Pharmacol 42: 482-485.

Roth BL, Baner K, Westkaemper R, Siebert D, Rice KC, Steinberg S et al (2002). Salvinorin A: a potent naturally occurring nonnitrogenous kappa opioid selective agonist. Proc Natl Acad Sci USA 99: 11934-11939.

Roth BL, Ernsberger P, Steinberg S, Rao S, Rauser L, Savage J et al (2001). The in vitro pharmacology of the $\beta$-adrenergic receptor pet ligand (s)-fluorocarazolol reveals high affinity for cloned $\beta$-adrenergic receptors and moderate affinity for the human 5-HT1A receptor. Psychopharmacology 157: 111-114.

Roth BL, Sheffler DJ, Kroeze WK (2004). Magic shotguns versus magic bullets: selectively non-selective drugs for mood disorders and schizophrenia. Natl Rev Drug Discov 3: 353-359.

Rothman RB, Baumann MH, Savage JE, Rauser L, McBride A, Hufeisen SJ et al (2000). Evidence for possible involvement of 5-HT2B receptors in the cardiac valvulopathy associated with fenfluramine and other serotonergic medications. Circulation 102: 2836-2841.

Sesack SR, Pickel VM (1992). Prefrontal cortical efferents in the rat synapse on Unlabeled neuronal targets of catecholamine terminals in the nucleus accumbens septi and on dopamine neurons in the ventral tegmental area. J Comp Neurol 320: $145-160$.

Shapiro DA, Kristiansen K, Weiner DM, Kroeze WK, Roth BL (2002). Evidence for a model of agonist-induced activation of 5-hydroxytryptamine $2 \mathrm{~A}$ serotonin receptors that involves the disruption of a strong ionic interaction between helices 3 and 6 . J Biol Chem 277: 11441-11449.

Shi Q, Savage JE, Hufeisen SJ, Rauser L, Grajkowska E, Ernsberger $\mathrm{P}$ et al (2003). L-homocysteine sulfinic acid and other acidic homocysteine derivatives are potent and selective metabotropic glutamate receptor agonists. J Pharmacol Exp Ther 305: 131-142.

Sorg B, Kalivas P (1993). Effects of cocaine and footshock stress on extracellular dopamine levels in the medial prefrontal cortex. Neuroscience 53: 695-703.

Talvik-Lotfi M, Nyberg S, Nordstrom A-L, Ito H, Halldin C, Brunner F et al (2000). High 5-HT2A receptor occupancy in 
M100907-treated schizophrenic patients. Psychopharmacology 148: 400-403.

Thierry AM, Tassin JP, Blanc G, Glowinski J (1976). Selective activation of the mesocortical DA system by stress. Nature 263: 242-244.

Weinberger DR (1987). Implications of normal brain development for the pathogenesis of schizophrenia. Arch Gen Psychiatry 44: 660-669.

Westerink BHC, de Boer P, de Vries JB, Kruse CG, Long SK (1998). Antipsychotic drugs induce similar effects on the release of dopamine and noradrenaline in the medial prefrontal cortex of the rat brain. Eur J Pharm 361: 27-33.

Westerink BHC, Kawahara Y, De Boer P, Geels C, De Vries JB, Wikstrom HV et al (2001). Antipsychotic drugs classified by their effects on the release of dopamine and noradrenaline in the prefrontal cortex and striatum. Eur J Pharmacol 412: 127-138.

Williams G, Goldman-Rakic P (1995). Modulation of memory fields by dopamine D1 receptors in prefrontal cortex. Nature (London) 376: 572-575.

Willins DL, Deutch AY, Roth BL (1997). Serotonin 5-HT2A receptors are expressed on pyramidal cells and interneurons in the rat cortex. Synapse 27: 79-82.
Wroblewska B, Wroblewski JT, Pshenichkin S, Surin A, Sullivan SE, Neale JH (1997). $N$-acetylaspartylglutamate selectively activates mGluR3 Receptors in transfected cells. J Neurochem 69: $174-181$.

Xue C-J, Ng JP, Li Y, Wolf ME (1996). Acute and repeated systemic amphetamine administration: effects on extracellular glutamate, aspartate, and serine levels in rat ventral tegmental area and nucleus accumbens. J Neurochem 67: 352-363.

Yamamoto BK, Pehek EA (1990). A neurochemical heterogeneity of the rat striatum as measured by in vivo electrochemistry and microdialysis. Brain Res 506: 236-242.

Zahrt J, Taylor JR, Mathew RG, Arnsten AFT (1997). Supranormal stimulation of D1 dopamine receptors in the rodent prefrontal cortex impairs spatial working memory performance. J Neurosci 17: 8528-8535.

Zhang W, Perry KW, Wong DT, Potts BD, Bao J, Tollefson GD et al (2000). Synergistic effects of olanzapine and other antipsychotic agents in combination with fluoxetine on norepinephrine and dopamine release in rat prefrontal cortex. Neuropsychopharmacology 23: 250-262. 